\title{
TOLERANSI BERAGAMA KRAMA HINDU DAN ISLAM DI DESA KUSAMBA KECAMATAN DAWAN KABUPATEN KLUNGKUNG
}

\author{
Oleh: \\ I Made Yudabakti \\ Universitas Hindu Indonesia Denpasar
}

\begin{abstract}
ABSTRAK
Untuk mewujudkan lingkungan sosial yang damai, sejahtera, dan rukun dibutuhkan toleransi yang tinggi antar umat beragama. Toleransi dimaksud telah dibuktikan oleh masyarakat (krama) Hindu Bali dan Islam di Desa Kusamba, Dawan, Klungkung yang dilandasi beragam alasan, di antaranya historis, genetik, profesi, dan sosial. Selain hal di atas, tumbuhkembang dan terbinanya sikap toleransi antara karma Hindu dan Islam di Desa Kusamba telah melewati beberapa proses, antara lain: 1) pembinaan para tokoh atau pemuka agama, baik yang beragama Hindu dan yang beragama Islam; 2) pembinaan dari pihak Pemerintah melaui peran Departemen Agama Kabupaten Klungkung; 3) toleransi telah menjadi kebutuhan setiap individu; dan 4) tumbuhnya sikap toleransi dalam berbagai aktivitas. Pembinaan yang dilakukan telah tertata dan berkesinambungan menjadi sikap toleransi antara krama Hindu dan Islam di Desa Kusamba sampai saat ini. Semuanya telah berimplikasi pada kehidupan; kedamaian, berbhinneka tunggal ika, dan persatuan antara warga di Desa Kusamba.
\end{abstract}

Kata kunci: toleransi, keberagamaan, krama Hindu, krama Islam

\section{ABSTRACT}

To create a social environment that is peaceful, prosperous, and harmonious, high tolerance between religious communities is required. This tolerance has been proven by the Balinese and Islamic Hindu (krama) communities in the village of Kusamba, Dawan, Klungkung based on various reasons, including historical, genetic, professional, and social. Apart from the above, the growth and development of tolerance between krama Hindu and Islamic in Kusamba Village has gone through several processes, including: 1) fostering religious figures or leaders, both Hindu and Muslim; 2) guidance from the Government through the role of the Department of Religion of Klungkung Regency; 3) tolerance has become a need of every individual; and 4) growing tolerance in various activities. The guidance that has been carried out has been organized and sustainable into an attitude of tolerance between Hindu and Islamic manners in Kusamba Village to date. Everything has implications for life; peace, diversity, and unity among residents in Kusamba Village.

Keywords: tolerance, diversity, Hindu manners, Islamic manners 


\section{PENDAHULUAN}

Bali merupakan daerah yang mayoritas penduduknya beragama Hindu dengan pengelolaan sistem kemasyarakatan berdasarkan tradisi, budaya, dan agama (Hindu). Artinya, secara umum keberadaan masyarakat diwarnai oleh penciri atau nafas agama Hindu dalam berbagai aktivitas yang ditampilkan ke permukaan dalam aktivitas sosial. Hal ini dapat dibuktikan dengan banyaknya aktivitas ritual yang didominasi oleh masyarakat yang beragama Hindu dalam bentuk upacara yadnya. Hal tersebut berlaku atau dilaksanakan di seluruh wilayah Pulau Bali sebagai ciri atas Bali sebagai Pulau Dewata atau Seribu Pura. Dengan aktivitas masyarakat yang menampakkan aktivitas ritual keagamaan Hindu, bukan berarti tidak ada atau dibatasinya aktivitas agama lainnya (Islam, Kristen dan Budha). Terbukti agama-agama selain Hindu banyak melakukan ritual keagamaannya, akan tetapi tidak seperti ritual agama Hindu yang menampakkan orang-orang sarana-prasarana di mata publik.

$\begin{array}{rrr}\begin{array}{r}\text { Padatnya } \\ \text { keagamaan }\end{array} & \begin{array}{r}\text { berbagai } \\ \text { Hindu }\end{array} & \begin{array}{r}\text { aktivitas } \\ \text { seolah-olah }\end{array}\end{array}$ memarginalkan aktivitas agama-agama yang ada di Bali. Seperti keberadaan agamaagama yang ada pada kantong-kantong agama Islam di Kabupaten Klungkung yang terletak di beberapa tempat, antara lain: Desa gelgel, Banjar Lebih Kota Klungkung, dan Desa Kusamba Kecamatan Dawan Kabupaten Klungkung. Selain itu, di wilayah Karangasem terletak di Desa Kecicang, Desa Sidemen, dan di Kota Amlapura. Umat Islam di kedua kabupaten tersebut juga selalu melakukan ritual, seperti sunatan, perkawinan, dan hajatan haji namun tidak terlalu nampak mendominasi. Hal tersebut diakibatkan oleh jumlah umatnya masih minoritas. Selain itu, agama Budha banyak melakukan aktivitas ritual di wihara-wihara yang ada di Bali dalam berbagai bentuk, seperti perayaan Hari Raya Imlek dan lain-lainnya. Demikian pula agama Kristen banyak melakukan aktivitas keagamaan terkait dengan perayaan hari raya Natal dan Tahun Baru. kesimpulannya semua agama tersebut di atas tidak terlalu nampak di publik aktivitasnya sehingga seolah-olah mereka tanpa aktivitas ritual seperti agama Hindu.

Tampaknya berdasarkan asumsi peneliti sementara, berlangsungnya berbagai aktivitas ritual keagamaan dari berbagai agama di Bali berlangsung dengan damai diakibatkan oleh rasa toleransi yang masih kental di antara penganut agama-agama tersebut. Hal itu pertanda bahwa penghargaan terhadap keberagamaan agama masih berjalan baik. Demikian pula yang terjadi di Desa Kusamba Kecamatan Dawan Kabupaten Klungkung, dimana antara krama Hindu dan Islam sampai saat ini masih dapat hidup berdampingan tanpa adanya gejolak yang terjadi.

Sesuai uraian di atas, sejatinya di Bali penampakan aktivitas masyarakat pada publik bukan saja berupa aktivitas bernuansa agama Hindu, akan tetapi ada aktivitas dari agama-agama lainnya. Semestinya sikap tidak cenderung menonjolkan diri inilah penting untuk dipelihara sehingga tidak muncul berbagai persoalan. Mengingat sikap tidak berlebih-lebihan adalah implementasi dari rasa toleransi beragama untuk dapat harmonis berdampingan dengan penganut agama Hindu sewilayahnya. Keharmonisan yang terjadi antara dua agama atau lebih dalam sebuah kehidupan sosial memang suatu hal yang sangat amat jarang terjadi. Mengingat berdasarkan fakta yang terjadi banyak di antara pemeluk agama yang berbeda di luar Bali sering bentrok diakibatkan oleh kelemahan mengelola perbedaan tersebut. Semestinya perbedaan bila disikapi dengan baik justru akan tercipta 
menjadi sebuah adonan keharmonisan dalam kebinekaan. Keharmonisan akan terwujud apabila warga masyarakat mampu mengendalikan berbagai perilaku negatif, seperti menyulut perbedaan dengan penghinaan salah satu agama atau lebih suka mengalah atau menghargai segala perbedaan di antara mereka. Rupanya hal inilah yang menyebabkan terjadi keharmonisan dalam masyarakat yang multi agama. Kemampuan bertoleransi dalam masyarakat kebinekaan didasari oleh sikap harga-menghargai antara mereka. Toleransi dalam hal ini tidak berdasarkan takut karena dalam jumlah salah satu agama minoritas, atau sebaliknya berani karena jumlah salah satu agama mayoritas. Namun yang terpenting bagaimana menciptakan suasana persaudaraan dan rasa saling membutuhkan satu dengan yang lainnya. Seperti saling harga-menghargai adat, agama, atau perbedaan. Di samping itu, menghilangkan rasa fanatik atau mengagung-agungkan diri yang berujung pada pertikaian sosial. Selain itu, penting menghargai perkawinan berbeda agama dan mengembangkan silahturahmi antara penganut agama yang berbeda. Hal itulah sebagai awal dari toleransi di antara agama-agama yang berbeda yang berujung pada keharmonisan.

Terkait dengan hal di atas, intinya kehidupan toleransi yang terjadi sampai saat ini pada krama Hindu dan Islam di Desa Kusamaba, Kecamatan Dawan, Kabupaten Klungkung bermuara dari terpeliharanya rasa saling hormat-menghormati antara kedua agama. Secara kasat mata kehidupan mereka dapat berdampingan secara harmonis tanpa hal-hal yang negatif. Berdasarkan pengamatan peneliti di lapangan ada beberapa hal atau faktor yang menyebabkan terjadi keharmonisan kedua pemeluk agama tersebut, antara lain: adanya persamaan profesi, adanya hubungan kekeluargaan di antara mereka, dan lainlainnya. Persamaan profesi dimaksud adalah warga Desa Kusamba yang terdiri atas dua agama, yaitu Hindu dan Islam kesehariannya banyak yang berprofesi sebagai nelayan di pantai Kusamaba. Dengan persamaan profesi ini walaupun agama mereka berbeda namun dalam menjalani pekerjaan nelayan mereka sangat akrab (pergaulan) di bidang kelautan atau sebagai bendega. Artinya, sikap toleransi dan saling menghargai dalam profesi ini dapat dibina sangat baik seolaholah tidak nampak mereka berbeda agama atau keyakinan. Aktivitas mereka hanya tampak satu sebagai nelayan yang pekerjaannya berurusan dengan hal penangkapan ikan dan pengelolaan koperasi nelayan dan lain-lainya. Selain itu, tumbuhnya toleransi kedua pemeluk agama tersebut diakibatkan karena adanya hubungan kekeluargaan di antara mereka, seperti: terjadi perkawinan seorang gadis yang beragama Islam dengan pemuda yang beragama Hindu atau sebaliknya seorang gadis yang beragama Hindu menikah dengan pemuda yang beragama Islam. Jadi dapat disimpulkan bahwa anak-anak yang dilahirkan perkawinan beda agama tersebut akan melahirkan insan-insan yang berdarah atau memahami sikap toleransi. Dalam hal ini sikap toleransi beragama telah terbina dari sebelum terjadinya perkawinan di antara mereka. Hubungan kekeluargaan yang terjalin sangat erat ini menyebabkan kedua pemeluk agama tersebut sulit untuk berpisah. Artinya, rasa toleransi mereka semakin hari semakin tumbuh menjadi sebuah perkampungan yang multikutural. Dalam keadaan itu hidup dan berkembangnya sikap bertoleransi masyarakat yang berbeda agama yang direkatkan oleh pemaham makna Bhinneka Tunggal Ika. Masyarakat yang berkebinekaan salah satu cirinya adalah dapat hidup berdampingan didasari oleh sikap toleransi dan saling harga-menghargai. Berdasarkan pengamatan peneliti sementara dapat diasumsikan di Desa Kusamba telah 
terjadi sikap bertoleransi antara krama Hindu dengan krama Islam dengan penampakannya mereka dapat hidup damai tanpa adanya pertikaian. Dalam hal ini ada beberapa persoalan yang penting mendapat jawaban dalam tulisan ini. Semuanya bertujuan untuk memberikan keterangan yang jelas kepada pembaca terkait dengan terjadinya toleransi beragama antara karma Hindu dan Islam di Desa Kusamba. 1) alasan terjadi toleransi beragama krama Hindu dan krama Islam di Desa Kusamba, Kecamatan Dawan, Kabupaten Klungkung; 2) proses terjadinya toleransi beragama krama Hindu dan krama Islam di Desa Kusamba, Kecamatan Dawan, Kabupaten Klungkung; dan 3) implikasi toleransi beragama krama Hindu dan krama Islam di Desa Kusamba, Kecamatan Dawan, Kabupaten Klungkung. Selanjutnya akan dijawab pada uraian pembahasan berikut.

\section{PEMBAHASAN}

Dalam draf ini diuraikan hasil bahasan dari jawaban tiga persoalan yang muncul dalam latar belakang di atas. Dengan demikian akan diperoleh karya tulis yang berkualitas dan berdasarkan hasil penelitian yang mendalam yang didukung dengan data-data yang akhurat. Ketiga jawaban persoalan tersebut akan diawali dengan menguraikan 1) alasan terjmnadinya toleransi beragama antara karma Hindu dan Islam di Desa Kusamba; 2) proses terjadinya toleransi beragama antara karma Hindu dan Islam di Desa Kusamba; dan 3) implikasi toleransi beragama antara karma Hindu dan Islam di Desa Kusamba.

\subsection{Alasan terjadinya toleransi beragama antara karma Hindu dan Islam di Desa Kusamba}

Dalam artikel ini disebutkan beberapa alasan yang menyebabkan tumbuh dan hidupnya sikap toleransi krama Hindu dan Islam di Desa Kusamba sampai saat ini, antara lain: alasan historis, genetik, profesi, dan sosial. Semua alasan tersebut peneliti peroleh berdasarkan pengamatan dan penelitian yang mendalam di lapangan. Untuk lebih jelasnya di bawah akan peneliti uraikan semua alasan penyebab terjadinya sikap toleransi di Desa Kusamba secara rinci.

\subsubsection{Alasan Historis}

Secara historis yang menyebabkan terjalinnya kehidupan toleransi di Desa Kusamba antara krama Hindu dengan Islam berawal terjadinya pemberontakan Patih Maruti, di mana Raja Gelgel banyak mendatangkan bala pasukan dari Jawa untuk membantu memadamkan pemberontakan tersebut. Setelah takluknya Patih Maruti maka raja menempatkan pasukan dari Jawa yang beragama Islam di pesisir pantai Desa Kusamba. Mereka bertugas sebagai benteng pertahanan, untuk menahan bila ada ancaman musuh yang datangnya dari sebelah timur. Dengan demikian, kerajaan Gelgel sebagai sasuhunan raja-raja di Bali tetap ajeg.

Alasan lainnya yang melatar belakangi tumbuhnya kehidupan toleransi di Desa Kusamba antara karma Hindu dengan Islam adalah setelah terjadi ketegangan politik antara I Dewa Agung Istri Kanya selaku penguasa Kerajaan Klungkung dengan pemerintahan Belanda yang ingin menguasai Klungkung pada pertengahan abad ke-XIX. Sampai akhirnya pecah peristiwa Perang Kusamba yang terjadi pada tanggal, 24 sampai dengan 25 Mei 1849 yang dimenangkan oleh pihak kerajaan Klungkung dengan terbunuhnya seorang Jendral Belanda yang bernama Jendral Michels. Hal tersebut terjadi tidak terlepas dari peran serta tentara Islam yang ditempatkan di Desa Kusamba, di mana mereka menjadi pasukan berani matinya Kerajaan Klungkung. Ketika pasukan tersebut kembali ke Desa Kusamba, tentara 
tersebutlah yang bertugas sebagai ujung tombak untuk mengacaukan bala pasukan Belanda sehingga Kerajaan Klungkung memperoleh kemenangan.

Atas jasa pasukan Islam tersebut dalam peperangan melawan Belanda lalu mereka diberikan tempat (wilayah tempat tinggal) tersendiri untuk mengurus komunitasnya tersendiri (daerah otonom) di Desa Kusamba. Dengan demikian, sampai saat ini wilayah tempat tinggalnya menjadi sebuah Desa otonom yang bernama Desa Kampung Kusamba.

Dalam catatan sejarah lainnya disebutkan bahwa Desa Kampung Kusamba, Klungkung memiliki ikatan yang sangat besar atas perkembangan Islam di Tanah Dewata. Bukti sejarah tersebut ditandai dengan adanya makam Habib Ali Bin Abubakar Bin Umar Bin Abubakar Al Hamid. Letaknya tepat di pesisir pantai Desa Kusamba, Klungkung. Semasa hidupnya Habib Ali dikenal sangat dekat dengan keluarga Kerajaan Klungkung. Bahkan, ia ditunjuk menduduki jabatan sebagai penerjemah atau ahli bahasa yang bertugas mengajarkan bahasa Melayu kepada raja yang saat itu dipimpin oleh Raja I Dewa Agung Jambe.

Sesuai pemaparan sejarah di atas, peneliti dapat analisis bahwa atas jasa para warga Islam dalam perang melawan tentara Belanda, maka pihak kerajaan Klungkung sebagai penguasa yang menganut agama Hindu tidak ada alasan untuk tidak menghormati jasa-jasa mereka (warga Islam di Desa Kusamba). Terbukti sang raja telah memberikan tempat tinggal untuk menetap para tentara tersebut di wilayah sekitar pantai Desa Kusamba sampai sekarang. Rasa hormat ini tentu saja harus diikuti oleh rakyat raja Klungkung yang beragama Hindu di Desa Kusamba dari dahulu kala sampai saat zaman modern ini. Atas pengawasan sang raja dari dahulu kala rasa toleransi tersebut tetap diwarisi dan tumbuh hingga kini. Itulah alasan sejarah mengapa terjadi toleransi antara karma Hindu dengan Islam di Desa Kusamba sampai saat ini.

\subsubsection{Alasan Genetik}

Selain alasan historis ada alasan genetik sebagai pemicu terjadinya toleransi beragama antara krama Hindu dan Islam di Desa Kusamba. Hubungan genetik ini telah menumbuhkan sikap toleransi antara warga Hindu dan Islam di Desa Kusamba sampai saat ini. Terjadinya hubungan genetik ini disebabkan oleh dua hal, antara lain: 1) perkawinan dan 2) keluarga atau keturunan sedarah beda agama.

\section{a. Perkawinan}

Perkawinan adalah sebuah hubungan seorang lelaki dengan wanita yang ditempuh melalui proses ritual sesuai dengan agama yang diyakinini atau dianutnya. Lewat perjalanan perkawinan inlah kedua insan akan melahirkan putra-putri percampuran darah dari kedua orang tuanya yang berasal dari keluarga yang berbeda etnis maupun agama. Seperti yang terjadi pada beberapa warga di Desa Kusamba dari warga yang beragama Hindu dan Islam. Hal ini sebagai salah satu penyebab terjadinya atau tumbuhnya sikap toleransi. Hal ini bermula dari adanya hubungan darah antara beberapa keluarga yang berbeda agama yang telah melakukan perkawinan. Artinya, ada beberapa pemuda Hindu yang mengawini gadis yang beragama Islam dan sebaliknya pemuda Islam yang mengawini gadis yang beragama Hindu. Hubungan darah di antara putra-putri mereka yang berlangsung dari dahulu kala sampai saat ini telah membawa kedekatan secara genetik maupun secara psikologis. Semua ini akan membentuk sifat-sifat toleransi atau berpengaruh terhadap kesadaran toleransi yang bermula dari keluarga, yakni pihak ayah atau ibunya. Dalam hal ini pendidikan saling harga menghargai dan toleransi agama sudah 
tertanam dari keluarga campuran tersebut. Sikap toleransi yang berhubungan dengan genetik ini akan semakin tumbuh subur bila warga mau melakukan beberapa perilaku-perilaku yang positf, seperti mau mengunjungi hajatan upacara keagamaan Hindu yang dilakukan oleh orang tuanya atau keluarga besarnya, di antaranya: upacara ngaben, metatah, perkawinan, odalan, mecaru, dan lain sebagainya oleh pihak keluarga (gadis) Hindu yang kawin dengan warga Islam, b) sebaliknya kunjungan pada upacara warga Islam, seperti Idul Fitri, Maulid Nabi, Sunatan, dan lain sebagainya oleh pihak warga (gadis) Islam yang kawin ke warga Hindu.

\section{b. Warga Sedarah Beda Agama}

Perkawinan dari warga yang berbeda agama akan melahirkan anak-anak yang berdarah campuran (Hindu dan Islam) atau diistilahkan dengan warga atau anak sedarah beda agama. Anak-anak yang lahir dari perkawinan beda agama ini akan melahirkan pola pikir yang berlandaskan konsep toleransi atau sikap saling hargamenghargai. Dalam hal ini yang menjadi pokok pikiran adalah tumbuhnya anak-anak yang mempunyai kemampuan beradaptasi dalam perbedaan, yaitu dalam kehidupan sosial. Anak-anak berdarah campuran ini secara tidak langsung telah diperkenalkan dengan sifat dan sikap toleransi. Artinya, mereka tidak lagi fanatik terhadap saudaranya yang berasal dari keluarga ibunya atau bapaknya. Dengan demikian, dari pihak anak-anak yang lahir dari percampuran darah ini isu tentang sikap toleransi dikumandangkan. Terutama terhadap orang-orang yang masih fanatik dengan perbedaan di lingkungan kelurganya atau masyarakatnya yang ada pada wilayahnya berasal.

\subsubsection{Alasan Profesi}

Dalam Kamus Besar Bahasa Indonesia (2008:1104) kata profesi berarti bidang pekerjaan yang dilandasi pendidikan keahlian (keterampilan, kejujuran, dan lain sebagainya) tertentu. Untuk memperoleh suatu keahlian lazimnya ditempuh dengan pembelajaran dalam sistem formal, seperti lewat sekolah-sekolah. Selain itu, dilakukan dalam pendidikan non formal yang biasanya lewat pengalaman dalam lingkungan suatu pekerjaan tertentu. Pengalaman non formal ini menyebabkan seseorang ahli dalam suatu bidang pekerjaan, seperti menjadi montir sepeda motor, juru ketik, menjadi nelayan, dan lain sebagainya.

Terkait dengan hal di atas, terjadinya atau tumbuhnya sifat dan sikap toleransi beragama antara krama Hindu dan Islam di Desa Kusamba salah satunya disebabkan dari adanya kesamaan profesi masyarakat atau warga dalam kehidupannya. Menurut analisa peneliti dan berdasarkan sumber data-data lapangan dari berbagai sumber informan, masyarakat setempat dominan menggeluti pekerjaan yang berkaitan dengan perairan laut atau sebagai nelayan. Hal ini dilakukan mengingat secara geografis daerah Kusamba terletak di daerah pesisir pantai. Dengan demikian, dapat dikatakan pekerjaan warga yang berdomisili di tepi pantai berkaitan dengan pekerjaan kelautan atau hasil laut. Di antaranya berprofesi sebagai nelayan (penangkap ikan), penjual ikan, bekerja sebagai pengelola kapal penumpang trayek Nusa Penida, bekerja sebagai buruh di pelabuhan Kusamba, dan lain sebagainya. Beberapa profesi yang dapat menjamin kehidupan telah dilakukan oleh warga se-Desa Kusamba, baik yang beragama Hindu maupun yang beragama Islam. Aktivitas tersebut disadari atau tidak disadari telah menumbuhkan rasa solidaritas antara warga seprofesi. Setelah peneliti analisa, berbagai pekerjaan kelautan ini sangat memerlukan keakraban dalam 
menjalaninya, tanpa itu maka pekerjaannya tidak akan pernah selesai. Untuk itu mereka dituntut untuk dapat hidup berdampingan satu sama lainnya walau agama mereka berbeda. Sikap inilah yang dinamakan toleransi dalam pekerjaan. Seiring dengan perjalanan waktu, sikap toleransi lambatlaun akan tumbuh subur dalam kesamaan profesi tersebut. untuk lebih jelasnya peneliti akan paparkan dua profesi penting (inti) yang dapat menumbuhkan sikap toleransi di Desa Kusamba, antara lain: profesi nelayan dan penjual jasa penyeberangan.

\subsubsection{Alasan Sosial}

Sosial berarti sesuatu yang berkenaan dengan masyarakat, atau perilaku suka memperhatikan kepentingan umum demi kesejahteraan dan kedamaian hidup bersama. Dalam kehidupan sosial manusia selalu berinteraksi kepada setiap individu yang berada pada suatu populasi tertentu. Dalam hal ini diperlukan usaha untuk memelihara kehidupan sosial dengan jalan memelihara hubungan antar warga masyarakat. Dengan demikian, manusia akan tergantung dengan hubungan atau interaksi sosial untuk menjaga citra dirinya dalam kehidupan masyarakat. Di samping itu untuk mencari/meningkatkan prestise dan citra diri dalam masyarakat, berbagai usaha akan dilakukan untuk mendapatkan pengakuan sosial.

Terkait dengan uraian di atas, masyarakat di Desa Kusamba dalam kehidupannya terus-menerus menumbuhkan hubungan sosial antar warga setempat. Walaupun agama dan pekerjaan mereka berbeda satu dengan yang lainnya. Berbagai usaha dan gerakan positif dilakukan untuk menjaga dan mendapat pengakuan sosial. Seperti halnya krama Hindu dan Islam di Desa Kusamba selalu menjaga rasa solidaritas antara warga setempat. Terlebih lagi masyarakat di Kusamba kini sikap toleransinya sudah terwujud, terbukti mereka bisa beradaptasi antar warga dalam keadaan apapun. Dalam aktivitas (pekerjaan) apapun kedua warga (Hindu dan Islam) di Kusamba selalu melandasi perilakunya dengan sikap saling hargamenghargai, menyayangi, dan selalu bertoleransi. Ini sebagai pertanda masyarakat di Kusamba telah memahami betapa pentingnya hidup bersama dan bersatu untuk menyelesaikan pekerjaan. Adapun sendi-sendi kehidupan sosial dipelihara oleh masyarakat di Desa Kusamba, seperti: menjaga hubungan baik dalam pekerjaan atau profesi yang berlandaskan toleransi, yaitu terbuka dan saling harga-menghargai. Dari sikap ini akan menumbuhkan rasa sosial karena setiap warga sangat mementingkan rasa damai, rasa hidup bersama, rasa bersatu, dan rasa hidup dihargai sehingga dapat hidup berdampingan dalam masyarakat. Karena alasan sosial inilah warga Kusamba mau melakukan sikap toleransi beragama dalam masyarakat yang plural. Pengakuan sosial sangat dipentingkan oleh setiap orang, tanpa ini manusia akan terasa tidak berhagai dalam hidupnya. Ada beberapa hal penting telah dilakukan oleh kedua belah pihak, yaitu para pemuka umat selalu merawat, mensosialisasikan, menumbuhkan pentingnya sikap toleransi dikembangkan atau dipertahankan dalam berbagai kegiatan sehingga sampai saat ini toleransi masih terjaga dengan baik. Walaupun masih terjadi perbedaan pendapat tentu masih dapat diatasi oleh para pemuka agama kedua belah pihak.

\subsection{Proses terjadinya toleransi beragama antara karma Hindu dan Islam di Desa Kusamba}

Dalam Kamus Besar Bahasa Indonesia (2008:1106) Proses adalah runtunan perubahan atau peristiwa dalam perkembangan sesuatu. Dalam hal ini sebagaimana terjadinya sikap toleransi 
beragama antara karma Hindu dan Islam di Desa Kusamba yang terjadi melalui proses yang perlahan dari waktu ke waktu secara kontinyu. Adapun proses terjadinya atau munculnya rasa dan sikap toleransi antar karma Hindu dan Islam di Desa Kusamba, yakni melalui: 1) penyuluhan pemuka agama; 2) Penyuluhan dari Pemerintah; 3) Toleransi menjadi kebutuhan setiap individu; dan 4) Tumbuhnya sikap toleransi dalam berbagai aktivitas.

\subsubsection{Toleransi Menjadi Kebutuhan Setiap Individu}

Berdasarkan usaha dan perjuangan para tokoh masyarakat di Desa Kusamba baik yang beragama Hindu maupun yang beragama Islam maka penanaman sikap toleransi sudah tumbuh subur. Hal itu dapat dibuktikan dalam kehidupan sosial, warga dapat hidup berdampingan dan saling hargamenghargai dalam berbagai aktivitas. Dengan demikian, mereka dapat menjalankan berbagai usaha untuk kepentingan mencari nafkah hidup seharihari atau menjalankan usaha untuk meningkatkan perekonomian. Dengan adanya rasa aman dan nyaman dalam kehidupan sosial (tanpa adanya sekat-sekat sosial) maka warga setempat akan dapat menjalankan tujuan hidupnya dengan baik. Hal inilah yang telah terwujud, yaitu sikap toleransi yang sudah menjadi kepentingan hidup. Tumbuhnya hal ini harus diusahakan dengan dibina secara kontinyu dan diawasi secara intensif layaknya memelihara tanamtanaman untuk mendapat hasil yang baik dan bermanfaat bagi kehidupan kita di dunia ini. Jika hal toleransi telah terbukti mampu mandamaikan pikiran dan sikap warga di Desa Kusamba maka mereka tidak raguragu lagi untuk melakukan antara warga yang berbeda agama.

Adapun hal-hal yang dilakukan terkait dengan pemeliharaan sikap toleransi, yakni meliputi: 1) selalu menjaga batasan- batasan dalam berbicara dan berbuat agar tidak menyinggung orang lain, 2) selalu berperilaku yang pantas dalam kehidupan sosial, 3) tidak menonjolkan sikap fanatik agama terhadap penganut agama lainnya ,4) tidak memancing-mancing dengan pembicaraan-pembicaraan yang bersifat sensitif, seperti: agama, etnis, sara, konflik, dan lain sebagainya. Dengan membina dan menanamkan pemahaman terhadap pentingnya dipelihara sifat dan sikap toleransi maka kehidupan sosial akan menjadi damai dan sejahtera. Dengan demikian, toleransi di Desa Kusamba kini telah menjadi kebutuhan pokok bagi warga yang hidup di desa setempat sampai saat ini. Tanpa semua itu maka kehidupan mereka akan menjadi tercerai berai antar warga yang satu dengan yang lainnya. Maka tidak ada alasan bagi setiap warga untuk tidak membina dan memelihara sifat dan sikap toleransi secara baik. Terkait dengan hal tersebut, setelah peneliti amati di lapangan para pemuka kedua agama di Kusamba selalu berusaha dengan sungguh-sungguh bersatu-padu membina dan menjaga agar sikap toleransi yang telah tumbuh subur dapat bertahan hidup untuk selamanya dari generasi ke generasi selanjutnya.

\subsubsection{Tumbuhnya Sikap Toleransi Dalam Berbagai Aktivitas}

Dengan tumbuhnya kesadaran warga di Desa Kusamba untuk bersikap toleransi terhadap warga yang berbeda agama (Hindu dan Islam) di lingkungan tempat tinggalnya tentu menyebabkan desa tersebut menjadi kondusif secara menyeluruh. Di samping itu, warga akan dapat melakukan berbagai aktivitas atau pekerjaan terkait dengan pembangunan desanya. Terbukti dalam beberapa pekerjaan yang memerlukan banyak tenaga manusia dilakukan oleh kedua warga yang berbeda agama dengan harmonis. Tumbuhnya hal ini di satu sisi karena mereka memerlukan pekerjaan untuk 
penghidupan. Di sisi lain mereka berkewajiban untuk menjaga budaya toleransi yang telah terpatri dengan baik dari dahulu sehingga tidak ternodai oleh perbuatan negatif. Untuk menjaga rasa toleransi tetap baik mereka lebih mengutamakan menjalankan pekerjaan berdasarkan kesepakatan. Hal ini dilakukan dengan mengawali mengambil keputusan sebelum memulai suatu pekerjaan agar dikemudian hari tidak terjadi percekcokan yang menyebabkan terjadi perpecahan atau beda pendapat Hal-hal yang perlu disepakati, misalnya: ketaatan dalam bekerja, perhitungan ongkos kerja, kualitas kerja, dan lain-lainnya yang dianggap perlu diputuskan harus ditaati oleh kedua belah pihak agar tidak terjadi perselisihan di kemudian hari. Mengingat hal ini akan berdampak pada kualitas kerja dan yang terpenting adalah terjaganya rasa persaudaraan tetap ajeg. Dari keajegan itu akan terbentuk sikap toleransi antara pekerja yang berbeda agama.

Hal di ataslah sebagai dasar tumbuh kembangnya sikap toleransi antara karma Hindu dan Islam di Desa Kusamba saat ini. Mereka tidak ada yang mengedepankan wacana-wacana agama ke permukaan bila tidak terlalu penting. Hal yang penting ditonjolkan adalah penanaman rasa saling harga-menghargai antara teman dalam suatu profesi atau pekerjaan. Dengan demikian, sikap toleransi akan tumbuh subur dalam sebuah perbedaan yang akan menampakkan keharmonisan dalam hidup sosial ini.

\subsection{Implikasi Toleransi Beragama Antara Krama Hindu Dan Islam di Desa Kusamba.}

Terkait dengan hal di atas, ada beberapa implikasi dari penelitian ini yang dapat peneliti simpulkan, antara lain: manfaat kedamaian, manfaat ke-bhinnekaan, dan manfaat persatuan.

\subsubsection{Manfaat Kedamaian}

Terjadinya atau tumbuhnya sikap toleransi antara karma Hindu dan Islam di Desa Kusamba sangat berimplikasi pada kedamaian lingkungan. Terutama antara warga yang berbeda agama dalam lingkungan sosial. Adanya rasa aman dan damai dalam kehidupan sosial antara warga inilah manfaat dari sebuah perjuangan kontinyu yang kini telah terwujud di Desa Kusamba. Damai adalah suatu dambaan dari perjuangan setiap manusia hidup di masyarakat untuk menjalani hidup. Pada intinya terbinanya kehidupan toleransi yang telah diperjuangkan oleh kedua warga (Hindu dan Islam) di Desa Kusamba kini telah berimplikasi pada kedamaian dalam kehidupan masyarakat setempat. Keadaan damai masyarakat di Kusamba adalah sebagai modal dasar dalam masyarakat yang heterogen untuk melakukan pembangunan baik secara fisik maupun secara non fisik.

\subsubsection{Manfaat Bhinneka Tunggal Ika}

Sikap toleransi yang berkembang di Desa Kusamba saat ini sebagai salah satu tiang penguat dari pluralisme di Indonesia, yaitu hidup dalam keanekaan atau Bhinneka Tunggal Ika. Bertahannya atau ajegnya pola kehidupan yang ber-bhinneka Tunggal Ika di Indonesia didasari dengan sikap toleransi. Jika diibaratkan sebagai sebuah gedung yang tinggi tiang-tiang penyangganya adalah sebagai kekuatan intinya. Sedangkan tiangtiang dari bangunan Bhinneka Tunggal Ika di Indonesia adalah sikap toleransi yang telah ditumbuhkembangkan dan dipertahankan oleh masing etnis dan agama yang ada di wilayah ini.

Dengan terjadinya toleransi di Desa Kusamba antara karma Hindu dan Islam adalah sangat bermanfaat terhadap keberlangsungan atau terjaganya Bhinneka Tunggal Ika. Inilah sebagai implikasi dari penelitian yang sedang dilakukan untuk 
merajut perbedaan di antara semua warga dalam suatu wilayah.

\subsubsection{Manfaat Persatuan}

Persatuan adalah sebuah perjuangan panjang yang dilakukan dan dipertahankan oleh bangsa Indonesia dari masa kemerdekaan sampai saat era globalisasi ini. .Walaupun bangsa Indonesia secara yuridis telah mendapatkan kemerdekaannya, akan tetapi masih sering bangsa ini mendapatkan godaan-godaan yang berupa isu pemecahbelah secara internal atau eksternal. Secara internal isu perpecahan muncul diawali dari perbedaan pendapat antara para tokoh nasional yang kepentingan dan ideologinya berbeda. Hal ini bisa dengan mengaburkan pemahaman toleransi antara suku dan agama di masyarakat yang telah merdeka. Dengan demikian, seolah-olah negara Indonesia tidak mempunyai dasar negara dan ideologi lagi. Maka bermunculan wacana-wacana untuk mengganti dasar atau ideologi negara ini dengan paham lain sesuai kepentingan orang yang tidak jelas di mana mereka mendapat ideologi tersebut. Dengan banyaknya warga bangsa yang telah terprovokasi oleh isu tersebut maka suasana negara ini akan goncang dan akhirnya persatuan tidak pernah akan terwujud sesuai dengan bunyi sila ke-3 dari Pancasila, yaitu Persatuan Indonesia.

Untuk menyikapi persoalan di atas, negara dengan dukungan daerah-daerah provinsi harus sedini mungkin untuk menanamkan sikap toleransi bagi warga yang hidup di daerahnya masing-masing. Lebih-lebih pada era global ini kehidupan warga sudah hidup berbaur secara bebas tanpa adanya sekat-sekat etnis, agama, kelamin, dan lain sebagainya. Hanya dengan tumbuhnya sikap toleransi saja bangsa Indonesia akan dapat bertahan dalam keBhinnekaannya. Dengan adanya sebuah desa di Bali yang bernama Desa Kusamba telah menerapkan kebiasaan hidup bertoleransi antara warga yang beragama Hindu dan Islam tentu sangat diharapkan sebagai teladan dalam kehidupan bernegara di Indonesia. Hal ini telah terbina ketika masyarakat Kusamba masih berada di bawah kekuasaan raja-raja Klungkung. Hal ini salah satu alasan desa ini tetap ajeg menjaga sikap toleransi yang telah ditanamkan oleh nenek-moyang mereka baik dari warga yang beragama Hindu maupun warga yang beragama Islam. Sikap toleransi yang telah diwujudkan dalam tindakan hidup bermasyarakat tentu akan bermanfaat pada tumbuhkembangnya persatuan dalam lingkungannya.

Apabila beberapa daerah di Indonesia mau menjalankan sikap toleransi seperti saudaranya yang berada di Bali khususnya di Desa Kusamba tentu Indonesia ini akan terlepas dari kekacauan secara nasional. Inilah manfaat dari penelitian ini, yakni hasilnya akan bermanfaat untuk menjaga persatuan bangsa ini sesuai petunjuk dari sila ke-3 dari Pancasila, yaitu Persatuan Indonesia.

\section{PENUTUP}

Terjadinya toleransi beragama antara karma Hindu dan Islam di Desa Kusamba tumbuh subur seiring dalam perjalanan waktu yang amat panjang dari generasi ke generasi. Secara alami kedua etnis/agama tersebut hidup berdampingan dan bersinergis dalam berbagai aktivitas untuk menopang kehidupan mereka dari waktu ke waktu. Tampaknya perbedaan agama atau kepercayaan tidak menjadi penghalang ketika mereka menjalani kehidupannya, yang terpenting mereka dapat menyambung kehidupannya bersama anak-cucunya. Untuk itu mereka secara alami telah mengedepankan nilai-nilai moral dan sikap saling harga-menghargai antara warga di sekitarnya. Secara umum dalam hukum sosial hidup bertoleransi merupakan naluri yang secara otomatis pasti mereka harus 
lalui dan lakukan dalam hidup. Tanpa itu kehidupan mereka akan menjadi tidak menentu atau penuh persengketaan.

Terkait dengan hal di atas, masyarakat di Desa Kusamba setelah diamati secara saksama dalam penelitian ini telah melakukan kehidupan bertoleransi antara karma Hindu dan Islam sampai zaman global ini. Dalam hal ini ada beberapa alasan yang menyebabkan terjadinya toleransi beragama, antara lain: 1) alasan historis: yaitu adanya rasa sepenanggungan atau seperjuangan warga Hindu dan Islam ketika menghadapi tentara Belanda atas perintah raja Klungkung yang menjadi penguasa daerah Kusamba ketika itu. Rasa persatuan yang terjalin akibat peperangan zaman dahulu masih terpatri pada kehidupan masyarakat sampai saat ini dan hal itu telah ditularkan sampai sekarang kepada anak-cucu mereka walau kekuasaan raja Klungkung tidak ada lagi. 2) alasan genetik: terjadinya toleransi sampai saat ini di Desa Kusamba, diakibatkan oleh adanya perkawinan antara warga yang beda agama. Dengan demikian, akibat perkawinan tersebut beberapa warga akan ada yang genetikanya sama. Dari perkawinan ini kedua mempelai secara langsung atau tidak langsung dituntut untuk bersikap toleransi terhadap suami atau istrinya dalam membina rumah tangga. Karena tanpa itu kehidupan rumah tangganya akan ambruk dan cenderung mengalami perceraian. Akibat perkawinan beda agama ini lahirlah putraputri yang berdarah campuran yang akan merespon tumbuhnya sikap toleransi yang berdampak pada lingkungan sekitarnya. 3) alasan profesi: terjadinya toleransi di Desa Kusamba diakibatkan oleh kesamaam profesi atau pekerjaan. Dalam menuntaskan pekerjaan setiap orang atau warga akan dituntut untuk bersikap toleransi terhadap teman sekerjanya walau mereka berbeda agama. Adapun pekerjaan yang menuntut dengan sikap toleransi di Kusamba, antara lain: pekerjaan nelayan dan penjual jasa penyeberangan. Kedua pekerjaan tersebut dituintut kebersamaan dan sehati agar pekerjaannya dapat berjalan dengan baik dan dapat mendapatkan hasil yang maksimal untuk memenuhi kebutuhan hidupnya. Dan 4) alasan sosial: adanya tuntutan sosial dalam kehidupan berwarga di masyarakat bila dapat berlaku atau bersikap toleransi. Tanpa sikap itu mereka akan merasa terkucilkan dalam pergaulan hidup sosial. Semua itu akan diperoleh lewat pergaulan sehari-hari, pekerjaan, dan berbagai aktivitas lainnya.

Selain hal di atas, ada beberapa proses yang dilakukan oleh kedua warga berbeda agama di Desa Kusamba dalam membina toleransi, antara lain: 1) penyuluhan dari pemuka agama baik yang beragama Hindu maupun yang beragama Islam. Penyuluhan ini dimotori oleh masingmasing pimpinan keagamaan setempat untuk meningkatkan sikap toleransi beragama para warga di wilayah Desa Kusamba. Semua itu dilakukan lewat aktivitas ritual keagamaan masing-masing; 2) penyuluhan dari Pemerintah, dilakukan oleh pihak pemerintah lewat peran Departemen Agama Kabupaten Klungkung atas permintaan warga masing-masing agama. Hal itu secara umum bertujuan untuk mengingatkan pentingnya penerapan dan pembinaan sikap toleransi agar tetap dipelihara; 3) Toleransi menjadi kebutuhan setiap individu, hal ini berarti bahwa hidup dalam perbedaan untuk mencapai tujuan kedamaian dan kesejahteraan toleransi merupakan kebutuhan yang pokok dan penting; dan 4) tumbuhnya sikap toleransi dalam berbagai aktivitas, dengan proses pembinaan sikap toleransi dan setelah warga dapat merasakan manfaatnya maka mereka akan terus membina hal itu secara berkesinambungan. Mengingat saat ini hidup bertoleransi sudah tumbuh dalam berbagai aktivitas warga. 
Implikasi dari penelitian ini terdiri atas tiga, antara lain: 1) berimplikasi pada kedamaian, hal ini berarti akibat pembinaan secara kontinyu sikap toleransi bagi warga Hindu dan Islam di Desa Kusamba kini sangat bermanfaat pada kedamaian dalam kehidupannya. 2) berimplikasi pada Bhinneka Tunggal Ika, terbinanya sikap toleransi antara karma Hindu dan Islam di Desa Kusamba bermanfaat pada terbangunnya kehidupan berbhinneka Tunggal Ika sesuai dengan lambing negara kita. Dalam keadaan desa seperti Kusamba yang telah melaksanakan hidup bertoleransi sudah pasti kehidupan multi kultur dapat dihargai dan berkembang dengan baik. Dengan demikian, bangsa Indonesia menjadi kuat dalam kehidupan berbeda. Dan 3) berimplikasi pada persatuan, berarti bahwa dengan terjadinya kedamaian hidup masyarakat di Desa Kusamba akibat penerapan sikap bertoleransi antara karma Hindu dan Islam akan menumbuhkan dan terbangunnya rasa dan wujud nyata persatuan telah tercapai sesuai dengan bunyi sila ketiga dari Pancasila, yaitu persatuan Indonesia.

\section{DAFTAR PUSTAKA}

Anonim. 2018. Profil Desa Kusamba. Adminisatrasi Desa Kusamba.

Anonim. 2018. Profil Desa Kampung Kusamba. Admistrasi Desa Kampung Kusamba.

Alwilsol (2004), Psikologi Kepribadian, UMM Press

Angger, Ben. 2009. Teori Sosial Kritis Kritik, Penerapan dan Implikasinya. Yogyakarta: Kreasi Wacana.

Donder dan Wisarja. 2010. Mengenal Agama-Agama: Memperluas Wawasan Pengetahuan Agama Melalui Mengenal dan Memahami Agama-Agama. Surabaya: Paramita.

Freist, J \& Friest, Gregory (1998), Theories of Personality, Amerika: Mc Graw Hill.

Hall, Calvin S., \& Linzey, Gardner (2000), Teori-Teori Holistik (Organismik- Fenomenologis), Dr. A. Supratiknya (ed.), Jogjakarta: Kanisius.

Haryanto, Sindung. 2015. Sosiologi Agama Dari Klasik Hingga Postmodern. Yogjakarta: ArRuzz Media.

Nawawi, Hadari. 2005. Metode Penelitian Bidang Sosial. Yogjakarta: Gadjah Mada University Press.

Robert, Thomas B., Four Psychologies Applied to Education, 1975, New York, Hals Ted Press Dvision

Schroeder, Ralph. 2002. Max Weber tentang Hegemoni Sistem Kepercayaan. Yogjakarta: Kanisius 
Sifatu, Wa Ode. 2014. "Perubahan, Kebudayaan, Dan Agama Perspektif Antropoligi Kekuasaan". Denpasar: Program Pascasarjana Universitas Udayana

Smith, Mark K. , (1997), Carl Rogers, Core Conditions and Education, www. Infred.org/thinkres/et-rogers.htm\#intro.

Sueady, Ahmad. 2007. Politisi Agama dan Konflik Komunal Beberapa isu penting di Indonesia. Jakarta: The Wahid Institute.

Sugiyono. 2007. Metode Penelitian Administrasi. Bandung: Alfabeta.

Sugono, D. 2008. Kamus Besar Bahasa Indonesia Pusat Bahasa. Jakarta: PT. Gramedia Pustaka Umum.

Uchjana Effendy, Onong. 2003. Ilmu, Teori dan Filsafat Komunikasi. Bandung: PT. Citra Aditya Bakti. 